Revue d'histoire de l'enfance « irrégulière »

Le Temps de I'histoire

14 | 2012

Enfances déplacées. (I) en situation coloniale

\title{
Stolen Childhoods. Reforming Aboriginal and Orphan Children through Removal and Labour in New South Wales (Australia), 1909-1917
}

Naomi Parry

\section{(2) OpenEdition \\ Journals}

Electronic version

URL: http://journals.openedition.org/rhei/3404

DOI: 10.4000/rhei.3404

ISSN: $1777-540 \mathrm{X}$

Publisher

Presses universitaires de Rennes

\section{Printed version}

Date of publication: 30 December 2012

Number of pages: 141-163

ISBN: 978-2-7535-2194-0

ISSN: 1287-2431

Electronic reference

Naomi Parry, «Stolen Childhoods. Reforming Aboriginal and Orphan Children through Removal and Labour in New South Wales (Australia), 1909-1917 », Revue d'histoire de l'enfance « irrégulière » [Online], 14 | 2012, Online since 30 December 2014, connection on 04 May 2019. URL : http:// journals.openedition.org/rhei/3404; DOI : 10.4000/rhei.3404

This text was automatically generated on 4 May 2019.

(c) PUR 


\title{
Stolen Childhoods. Reforming Aboriginal and Orphan Children through Removal and Labour in New South Wales (Australia), 1909-1917
}

\author{
Naomi Parry
}

1 Since 1996 in Australia, significant attention has been paid to the legacy of past practices towards children who had been displaced from their families by poverty, crime, the loss of family or deliberate policy. In that time, there have been three major government inquiries into the treatment of children and each has made it clear that Australian governments and welfare agencies failed the children in their care. In February 2008, the Australian Government apologized to the Aboriginal Stolen Generations and in November 2009, it apologized to the child migrants and 'Forgotten Australians' for their pain and suffering.

2 It is a sad fact of life that some children cannot be raised by their parents, owing to tragic circumstances such as death, illness, accident; or complicated factors such as poverty or family breakdown. In such circumstances, governments and welfare agencies purport to perform a protective function, providing 'care' and, as was often argued in the past, 'rescuing' them from adverse circumstances. The inquiries gave voice to those who grew up under these systems and the apologies recognise that, all too often, the alternative 'care' provided by governments and welfare agencies was loveless and uncaring and, at its worst, abusive. It is time to ask why policies designed to be helpful simultaneously produced such harm. It must also be acknowledged that Australian governments and welfare agencies played active roles in separating children from their families, either by failing to, or choosing not to, support families in crisis, or deliberately removing children from families defined as aberrant, in order to improve society - while policy-makers often stated destitute children needed protection, quite often they just intended to 
ensure society was protected from destitute children and their families. Historians must expose what motivated these actions, and the means by which they were justified to the public. ${ }^{1}$

3 This paper illustrates some of these motivations with a case study of a short but intensive period of policy development and review in New South Wales - Australia's largest state and the first to enact separate policies for Aboriginal children. It is drawn from a larger study into the welfare systems of New South Wales and Tasmania, in the period 1880 to 1940. ${ }^{2}$ In the years 1909 to 1917, the Aborigines Protection Board, a government agency, developed policies to remove Aboriginal youths from reserves and stations it controlled, and place them in private homes, and domestic servants or labourers. The goal was to reform the broader Aboriginal population by setting the younger generation to work, and it had embedded that practice by World War I. In the years 1916 to 1917, the New South Wales Government held two inquiries into the care of white children in its child welfare agency, the State Children's Relief Department [SCRD]. Unlike annual reports and other official government publications and records, inquiries test and contest policy. The questions asked within them expose the darker side of government-auspiced systems, and shed light on actual living conditions. That the inquiries endorsed the system, as it was, shows a broad tolerance of poor living conditions, and for overwork and actual physical abuse of the state's most vulnerable children, all justified by a belief that to do so prevented delinquency. Taken together, the policies of the Protection Board and the State Children's Relief Board reveal the forces of race, gender and class upon children, but also show the common expectation - that vulnerable children should work for their own good, and that they could not and should not expect better. This 'care', of the state's most vulnerable children, established a very low threshold for other 'care' systems, including non-government institutions and child migration schemes.

\section{The Inquiries}

4 As Swain, Sheedy and Musgrove have pointed out, the inquiries used the work of historians, as well as government submissions, but gave primacy to the testimony of those who lived through these systems. This provides a new archive on which historians can draw, and are fuel to campaigns for social justice and recognition of rights. ${ }^{3}$ An overview of the inquiries is presented here to establish the context of what has been recognised, and what yet needs to be done.

The first inquiry, into the separation of Indigenous children from their families, was the result of a long campaign of Aboriginal and Torres Strait Islander protests at the high rate of removal of children from their communities. ${ }^{4}$ Historians had been trying to bring this to national attention since the 1970s, and, in 1981 Peter and Jay Read coined the term 'stolen generation' to convey the Aboriginal community's sense of loss, and the wrongfulness of authorities in removing children ${ }^{5}$. At the request of the then Labor Government, the Australian Human Rights and Equal Opportunities Commission [HREOC] toured the country to interview 535 people affected by these policies, as well as welfare officers, policemen and carers. Historians also prepared submissions and gave evidence to the inquiry, and significant archival and other forms of research was conducted, often with the support of state governments. The result of this inquiry was the 1997 report Bringing them home: National Inquiry into the Separation of Aboriginal and Torres Strait Islander Children from their Families. ${ }^{6}$ The key findings of this report was that one in ten Aboriginal 
families had lost their children, and although some of these separations were necessary, because of death, family abuse and illness, governments and welfare agencies had adopted racist policies to actively separate children from their families. Aboriginal child rearing methods were condemned and families were judged incapable of caring for their children. The report stated that this was systematic racial discrimination, with the assimilationist goal of erasing the Aboriginality of children, and such actions contravened the United Nation's 1948 Universal Declaration of Human Rights and the Convention on the Prevention and Punishment of the Crime of Genocide. Furthermore, these policies had highly detrimental effects on the wellbeing of contemporary Aboriginal and Torres Strait Islander people. HREOC recommended an apology, reparations and the funding of systems to help reunify Aboriginal and Torres Strait Islander families.

6 State (provincial) governments did apologize, and provided funding and other forms of support to assist stolen generations to trace their family. However the Australian Government, which had changed to a conservative leadership in 1996, declared that, although the authorities' actions were regrettable, they had acted in children's 'best interests':

"The treatment of separated Aboriginal children was essentially lawful and benign in intent and also reflected wider values applying to children of that era, as recorded in other recent official reports concerning 'illegitimacy', adoption, child welfare and institutional practices throughout much of the twentieth century."

7 The Government argued that it was not responsible for removals so did not intend to pay compensation, and rejected the notion of an apology. This stance was buttressed by politically conservative commentators, who repudiated the oral history that formed the basis of many claims and insisted Aboriginal children were not stolen, but rescued from poverty, abuse and uncaring families and this was neither genocidal nor racist. ${ }^{8}$ The Government remained obdurate, and, eventually, debate stalled.

The reason the stolen generations received attention first was a long tradition of organisation and lobbying. Advocacy would soon bear fruit for other groups of affected people. From 1911 to 1972, the British Government had, through a number of religious and private organisations, organized the emigration of over 100,000 children to Australia and Canada, although Canada stopped admitting unaccompanied minors in $1925 .{ }^{9}$ Unlike earlier juvenile transportation, these new waves of children were not offenders. ${ }^{10}$ Awareness of this policy developed in the late 1980s, as the British-based Child Migrants' Trust advocated for child migrants, and released Lost Children of the Empire and Empty Cradles (the book on which the 2011 film Oranges and Sunshine was based). In Australia, the national broadcaster, the $\mathrm{ABC}$, aired a documentary based on Lost Children of the Empire (1989) and the mini-series The Leaving of Liverpool (1994), and studies of child migration were produced by Alan Gill and Geoffrey Sherington and Chris Jeffery. ${ }^{11}$ These highlighted that the child migrants had left institutional care in the UK, often without understanding what was happening to them, with the promise of better educational and work opportunities. For far too many the reality was a childhood of deprivation, forced labour, physical, psychological and sexual abuse, and a broken adulthood. This was compounded by problems securing birth certificates and passports and tracing relatives, caused by official and unofficial secrecy about the children's origins that had extended to telling children their parents did not want them or were dead. Many returned home to find that relatives were very much alive, and had no idea the children had been sent overseas. 
In 1996, the Western Australian state government, which had received the majority of child migrants to Australia, appointed a Select Committee into Child Migration. In 1998, the United Kingdom's House of Commons Health Committee conducted an inquiry led by David Hinchcliffe MP. Yet the Australian Government opposed attempts to establish a Senate Committee in 2000, saying it had assisted the Western Australian and British Government inquiries and offered financial support to the Child Migrant Trust and National Archives of Australia, to assist with family reunification. Only when the Forde Inquiry in Queensland released confidential reports about two notorious child migrant institutions in that state did the Australian Government relent.

In 2001, the Australian Senate produced Lost Innocents: Righting the record, which found that Australian agencies had accepted and institutionalised between five and 10,000 child migrants. ${ }^{12}$ These children were engaged in hard, often dangerous, physical labour to maintain and, in some cases build, the institutions they were housed in. The Committee identified a disturbing level of physical, sexual and psychological abuse within these institutions and stated Australian agencies had failed to exercise a duty of care over child migrants. The Committee acknowledged the argument of an advocacy group called Broken Rites, who have campaigned to draw attention to sexual assault in religious institutions that:

"It should be recognised that at the time child migrants were being "cared" for in so many institutions, the sexual assault of children was not sanctioned in any educational system in Australia, child labour was not permitted in law, slavery had been abolished, public beatings and floggings were no longer carried out in either the criminal justice system or in the military and minimum standards of working conditions, hours of work and wages had already been established for working adults." ${ }^{13}$

11 As the Committee concluded, such things were illegal then and are illegal now.

12 The conditions endured by child migrants only served to highlight those suffered by Australian-born children who grew up in out-of-home care. In the late 1990s, organizations, such as Care Leavers Australia Network and the Alliance for Forgotten Australians, formed to advocate for recognition of the legacy of their childhood. ${ }^{14}$ This culminated, in 2004, in a third Senate report, Forgotten Australians: A report on Australians who experienced institutional or out-of-home care as children. ${ }^{15}$ That Committee concluded that 500,000 Australians experienced care in an orphanage, home or other form of out-ofhome care in the $20^{\text {th }}$ century. After hearing evidence from hundreds of submissions of about lovelessness, emotional and physical deprivation and physical and sexual abuse, the Committee concluded that wide scale, unsafe, improper and unlawful care of children, a failure of duty of care and serious and repeated breaches of statutory obligations had occurred in the country's institutions, both state-run and religious. ${ }^{16}$ Yet the Australian Government said and did little in response.

13 In 2007, however, the 12 year old conservative government of Prime Minister John Howard was replaced by a Labor administration that chose, as its first act, to offer a formal apology to the stolen generations. New Prime Minister Kevin Rudd opened the 42nd Parliament on 13 February 2008 by apologizing to the stolen generations. After a further Senate report, Lost Innocents and Forgotten Australians Revisited, which highlighted the lack of government action, Rudd apologized to Child Migrants and the Forgotten Australians on 16 November 2009. Both apologies were matched by commitments of 
funding to help those who grew up in out of home care to locate their personal histories, assist in family reunion, and the provision of support services.

The Government's apologies can never undo the treatment suffered by children and their families but they do go some way towards accounting for the past. As Peter Read has said of the stolen generations, historians spent a lot of energy trying to establish that it even happened, and this prevented the telling of more subtle and complicated stories. ${ }^{17}$ The Government's apologies signify some level of community acceptance of these stories, and this provides space to consider the role and drivers of child welfare systems in Australian social history. This paper provides a case study for considering policy in New South Wales.

\section{The beginnings of child welfare policy in New South Wales}

The development of child welfare systems in New South Wales shows the way policymakers sought to protect society from children, while stating that it was protecting the children themselves. Since the beginning of the $19^{\text {th }}$ century, the NSW Government had paid churches and the Benevolent Society to fulfil its social welfare functions. This had led to destitute children being massed in their hundreds in the Protestant and Catholic Orphanages or the Randwick Destitute Children's Asylum. By 1860, the NSW Government had followed British leads by introducing industrial schools and reformatories, including training vessels, to deal with child convicts. On the one hand these were humanitarian, for they diverted children from adult jails, but on the other hand they were punitive, as they enabled the police and courts to apprehend children for being unsupervised or engaging in independent economic activity, such as street trading, or for being associated with prostitutes or thieves. These were status offences, and they led to the incarceration of thousands of children in institutions that survived until late in the $20^{\text {th }}$ century. ${ }^{18}$ By the 1870s however, the large orphanages were out of favour and decried internationally as 'barracks', and Tasmania, South Australia and Victoria had introduced boarding out. Activists such as the British sisters Florence and Rosamond Davenport Hill were amongst those who campaigned for the boarding-out of destitute children, arguing a family environment encouraged children's humanity and self-reliance. ${ }^{19}$ Their arrival in Sydney, in 1873, coincided with a Royal Commission and galvanised a group of reform-minded opinion-makers who generated pressure for change via the press and the pulpit. ${ }^{20} \mathrm{~A}$ Society of Ladies for Boarding-out Destitute Children developed, and in 1879, with the approval of Premier Sir Henry Parkes and the co-operation of the president of the Benevolent Asylum, Dr Arthur Renwick, 'experimented' by withdrawing children from asylums and boarding them in country homes. ${ }^{21}$ This process was formalized by the State Children's Relief Act of $1881 .{ }^{22}$ The new State Children's Relief Board [SCRB] was so active that the orphan asylums were closed within five years and although the Destitute Children's Asylum survived, it took far fewer children than it had before. ${ }^{23}$ Church organisations continued to run large orphanages, industrial schools survived until the 1970s and smaller institutions were developed for sick or mentally disabled children, but boarding-out was held to be the 'gold standard' for child welfare. $60 \%$ of state children were boarded out, with $30 \%$ being apprenticed as domestic workers and $10 \%$ living in institutions. ${ }^{24}$ Between 1881 and 1915, some 24,630 children were committed to the SCRD. of these, $63 \%$ were under the age of ten at the time they were committed. ${ }^{25}$ Boys 
predominated in both boarding out and institutions, with around 1.6 boys for every girl. ${ }^{26}$ Boy apprentices were also twice as popular as girl apprentices. ${ }^{27}$ The primary reason for this was the high value accorded to the labour of boys, which suited the SCRB's aspiration for them to become members of the industrious working classes.

The reasons children were committed varied - some were genuinely orphaned but others were surrendered by families that were broken by death, illness, divorce or poverty, or by single parents. In the late $19^{\text {th }}$ century, Australian states also developed child welfare systems in response to the increased visibility of children and social and economic deprivation. ${ }^{28}$ As Shurlee Swain and Dorothy Scott have observed, Australia looked to England for inspiration - local anxieties about neglected children and delinquency provided "narratives of darkness and light, evil and innocence, danger and rescue, which placed colonial dramas within an international context". ${ }^{29}$ After 1896, when the law in NSW was amended to enable the officers of the SCRD to apprehend children, removals occurred if children were judged neglected, or were visibly working on the street as newspaper boys or flower sellers, wandering, 'uncontrollable' or 'in moral danger'. ${ }^{30}$ Boarding out was presented as offering new hope for the children, and as a method of solving the problem.

The goal of boarding out was to replace a child's own, problematic, family with new bonds that were considered more wholesome, to prevent children from relapsing into pauperdom or adopting criminal habits. Underpinning this belief in the power of the 'good' family was the assumption that poverty and vice were bred in 'bad' families. Dr Arthur Renwick, the first President of the SCRB argued that the goal of 'rescue' was to supply 'artificial parental and filial love' through a foster parent, such love being 'nearly as genuine, and quite as practically useful as the love between two parents and children united by the ties of nature'. ${ }^{31}$ Renwick stated children would feel 'more thoroughly at home' with members of the skilled agrarian and working classes than they might with persons of higher social status, who were unable to perceive foster children as part of the household and thus would provide insufficient individual attention..$^{32}$ The only concession to the possible value of bringing children up in their own homes was another 1896 amendment, that enabled the SCRB to pay single mothers a half-rate of the boarding-out allowance to keep their own children - a measure which saved the SCRB money as well as preserved family bonds, although it did mean almost half of all children in state care were boarded with their own mothers from that point on. ${ }^{33}$ It is important to note that this payment was never extended to Aboriginal women. Seen as a privilege, rather than a right, it was withheld from Aboriginal women on racial and moral grounds.

An important element of boarding out was imparting habits of industry. Children were to be instructed in household work, so as to be qualified to 'go out into the world and fight the battle of life with credit to themselves and advantage to the commonwealth'. ${ }^{34}$ As children reached a 'useful age' they were placed in 'apprenticeship'. This was not trade training, but farm laboring for boys and domestic service for girls. They received pocket money and earned some wages, banked for them in trust and were supervised by their employers and occasionally inspected by SCRB staff. The exploitation inherent in the scheme was that the child defrayed the costs of its keep through labour, but the SCRB argued that such work was an extension of the family-centred work of boarding out. In effect, the boarding out and apprenticeship system meant children who had been visible on the streets, were rendered invisible by being placed, out of sight, in a new family. 
course placing children in a 'good family' immediately meant destroying the old family. To dodge this uncomfortable contradiction, Renwick, and many reformers who followed him, used the trope that state children were orphaned or abandoned. As his own department's figures showed most children in state care had at least one parent, he also used the qualifier 'actually or practically rendered orphans'. Orphans were the 'deserving poor', so their need for care could not be questioned, but they also provided an idealised image of a blameless child, deserving of rescue. The orphan had no parents whose rights might be trampled, or who could be accused of imposing their children upon the state, making it easier for the public to accept Renwick's argument that 'Children of the State' were 'children whom the State must father', 'virtually in loco parentis'. ${ }^{35}$

At the same time the SCRB was forming its ideas Aboriginal policy was beginning in NSW. Aboriginal culture maintained a toehold in rural areas, although the expansion of white settlement and marginalization of Aboriginal labour had led to what was simply termed 'the Aboriginal problem'. This was, essentially, the visibility of impoverished Aboriginal people around the fringes of towns, including the city of Sydney, and a growing population of people termed, in the offensive language of the day, to be 'half-caste' ${ }^{36}$. The presence of such people offended both charity and morality. As the Aborigines Protection Association, a short-lived quasi-missionary organisation, put it:

"Hundreds of young half-castes - the unmistakable tokens of the white man's sin are now running wild in the interior, being destitute of all physical comfort, and sunk in the lowest moral degradation. The females, many of them mere girls, are ruthlessly ruined, and thereby forced into a course of utter depravity. And these unfortunate women have no protectors, and no open door of hope!"37

The New South Wales Aborigines Protection Board was formed in 1883 to administer government aid to Aborigines, including blankets and rations, and make provisions for their welfare. It was a government agency, but did not follow the same approach as the SCRD; it never considered Aboriginal children were fit for boarding out, as there were no white families to take them (black families were never considered) and it was thought Aboriginal children could not adjust to white family life. Instead the Board believed 'younger half-castes should be withdrawn from the [Aborigines'] midst and gradually be absorbed into the general community'. ${ }^{38}$ Again, children - and Aboriginal people - were to be rendered invisible. By 1909 the Protection Board was ready.

\section{Child removal policy in NSW before World War I}

The tensions between the stated desire to protect children and the less obvious goal to protect society from children became apparent in the years just prior to World War I. Even as the Aborigines Protection Board began to consider child removal, child welfare policy was shifting. Sydney, a bustling New World port, also looked to Canada and cities like Boston, Chicago and New York for inspiration. As Tiffin has written, North American reformers looked to the child, a new focus of sociological inquiry, for national salvation. ${ }^{39}$ Older approaches, including children's protection societies, rescue and emigration movements, boarding out and legal and other measures against child abuse, were supplemented with new strategies, including family break-up, children's courts (beginning in Illinois), and institutional methods, some devised by African-American voluntary agencies. ${ }^{40}$ It is important to note that ideals of social justice frequently gave way to more punitive responses designed to preserve social order and middle class 
reformers, both sympathetic to and frightened by victims of poverty, enacted legislation to enforce parental (and especially maternal) responsibility for child supervision, rather than attempting to alleviate social conditions such as poverty. ${ }^{41}$ The same tensions played out in New South Wales, as it experimented with child welfare provision.

In 1902 the SCRD changed leadership, to Dr C.K. Mackellar, a physician, parliamentarian and activist for infant-life protection. ${ }^{42}$ Mackellar was highly energetic and, in 1905, introduced new laws, including Children's Courts. These softened the treatment of children who had been charged with crimes or status offences such as being 'uncontrollable' or 'in moral danger', as it removed them from adult courts, and a system of probation enabled more children to remain at home with their families, under supervision. This almost immediately reduced recidivism and slowed the rate of children being removed from their families. However, the Children's Court became the arbiter not just of criminal charges or neglect cases, but of all phases of welfare intervention, including regulating the payment of allowances to destitute mothers. Criminal regulation was thus combined with welfare intervention, indicating a growing focus on policing the lives and morals of the lower classes. Importantly, it provided a mechanism for removing children against the wishes of families. ${ }^{43}$

Mackellar was heavily influenced by the eugenic US family studies into the Jukes and the Kallikaks, which attributed social problems such as crime, immorality and incest to vicious circles of inbreeding and miscegenation. ${ }^{44}$ The SCRD already had cottage institutions for 'feeble-minded' children, but Mackellar's research into medical and psychiatric understandings of mental deficiency was part of a broad movement that united hereditarian and environmentalist assumptions and turned older ideals of child rescue towards a new goal: the curbing of delinquency. ${ }^{45} \mathrm{He}$ made it clear that the Children's Court was an instrument to weed out 'bad' families, headlining his 1907 Annual Report with an account of raids on an old gold mining district in the Monaro Plains, in southern NSW. Over several months, 67 families were prosecuted in rural Children's Court sessions and 113 children were removed for boarding-out or institutionalisation. Another 120 families, with 300 children, were cautioned. Those who kept their children were often relocated from a 'vicious environment' or the children were taken into care while the family's cottage was renovated. ${ }^{46}$ Mackellar said such cases proved that 'back blocks living' produced a nest of social problems, and all country districts should be investigated. ${ }^{47}$

In 1912, Mackellar was commissioned by the government to examine the treatment and management of mentally deficient and feeble-minded children in England, the United States and Europe, and produced an influential report. ${ }^{48}$ Amongst other recommendations, he suggested 'mentally deficient' women of child-bearing age should be detained. He included 'half-caste' women who lived on town fringes in his category of 'simple or moral imbecile', along with unmarried mothers and railway camp followers. ${ }^{49}$ This coincided with the Aborigines Protection Board's views that its own reserves were sites of uncontrolled female sexual activity and white men's vice, although the Board's responses were not eugenic, but were driven by older notions of rescue that were embedded in religious movements. ${ }^{50}$ In fact, the Protection Board developed policies that were quite different, both in race and gender terms, to those in the state welfare system.

The Aborigines Protection Board had sought to remove children since the 1890s, but had no legislative power to do so until 1909, when the Aborigines Protection Act was introduced. That Act was driven by the Board's Vice-President, George Edward Ardill, an energetic 
rescue worker who had established the Sydney Rescue Work Society, and founded women's refuges, lying-in homes and children's homes, whilst working as a missionary and serving as the Aborigines Protection Association secretary. Ardill did not believe in boarding out, and his own institutions were 'home-like', albeit funded by the labour of the inmates in his commercial laundries. Attacked for this by the Sydney labour movement, Ardill said such work helped the women 'to help themselves'. He believed 'the child of God must be useful', and like many religious reformers, felt placement in domestic service redeemed women who had fallen into degradation, vice, neglect and vicious surroundings. These were the same words he used to describe Aboriginal people. ${ }^{51}$

Ardill began informally apprenticing girls from Aboriginal stations from about 1898, and by 1907 was resolved upon a scheme to train Aboriginal children 'to proper spheres of usefulness' ${ }^{52}$ The legislation the Board created to do this defined an Aborigine as any person 'apparently having an admixture of Aboriginal blood' and gave the Board the power to control all lands set aside for Aboriginal people, to assume the rights of a father over any Aboriginal child, and to indenture any child of any Aborigine as an apprentice..$^{53}$ The Board said it was now 'clothed with ample powers' to compel 'the able bodied to shift for themselves' and to train the young to become 'useful members of the state'. ${ }^{54}$ Ironically, the Board used conditions on reserves, for which it was responsible, to justify the need to remove children, and the dichotomy between the desire to protect children, and protect society from children, is again clear:

"For years past it has been recognised that the various aborigines reserves throughout the State, - and indeed the Board's stations, - are far from suitable places to bring up young children. With such an environment it can hardly be expected that they will acquire those habits of cleanliness, obedience and morality which are so necessary if they are to become decent and useful members of the community. Some of the children are almost white, and if it were not that they are resident on an aborigines' reserve could hardly be distinguished from European children." ${ }^{55}$

28 As the Board developed its policies of apprenticeship and devised a flagship training institution, Cootamundra Girls' Home, were also explicitly intended to stem the 'alarming rapidity' of the growth in the population of 'half-castes, quadroons, and octoroons ${ }^{156}$. A new lady inspector was appointed to select girls for removal and place them in Cootamundra, and inspect their placements. The name chosen for this person was the 'Home-Finder', a term borrowed from Charles Loring Brace, who had claimed his Children's Aid Society's Western Emigration Programme 'rescued' New York's waifs, but had intended to break up pauper families. ${ }^{57}$ Once more, the trope of the 'orphan' was used: Cootamundra was initially called Home for Orphan and Neglected Children. ${ }^{58}$ But Ardill and the Protection Board focussed their attentions on youths, and, unlike the state welfare system where boys predominated, most were girls. Very few had no living parents.

Through a series of amendments carried out from 1915 to 1935 the Board gained the right to bind Aboriginal children to apprenticeship without Aboriginal consent, and worked with the SCRD (later known as the Child Welfare Department) to place lighter-skinned children in state care, via the Children's Courts. The number of children affected cannot be gauged at this stage, because light-skinned children were placed into state care and treated as if they were white. However, at least 1600 older children were apprenticed in the years 1916 to $1928 .{ }^{59}$ In 1915 , the Board was criticised by the SCRD for the manner in which it dealt with children. Then SCRD President A.W. Green drew a vivid picture of the 
state of Aboriginal family life on Board reserves, implying gross mismanagement and a eugenic nightmare:

"The women are easily accessible prey to itinerant hawkers, teamsters and tramps. Paternity is casual and conjectural, and promiscuous association is the rule; sanitation is ignored. Dirt is the dominating element. In this mire of physical and moral abasement, tended by semi-imbecile mothers, children are allowed to wallow through the imitative stages of childhood." ${ }^{60}$

At that time Green said the SCRD held 70-80 Aboriginal children who appeared white but 'beneath the skin' the 'taint is more marked'. While he complained that such children were placed amongst white children in state institutions, he still argued 'the correction of [Aboriginal children's] degenerate traits and the eradication of demoralised habits' was the work of the 'expert psychologist and educationalist' and ought to be conducted via the Children's Courts and Probation. However, the Board had also changed leadership, as its Vice-President Ardill was forced off the Board, and Green was dissuaded from his criticism. Board members agreed to allow SCRD officers to attend reserves, effectively forming a partnership. After his retirement, Green joined the Board. ${ }^{61}$

Despite this acquiescence to the SCRD the Board's practices remained different to those of the SCRD. At a time when the SCRD was adopting ideas that were progressive, such as educational programmes targeted at children's 'mental deficiency', the Board continued to use apprenticeship to redeem children by labour. ${ }^{62}$ The few records that survive show that, in the period 1905-1928, the average age of removal of Indigenous children was 13 years and 9 months, compared to the SCRD's average of 7 years and 4 months. Although the Board wrote about the need to deal with orphans and neglected children, Aboriginal children had living parents with children who remained at home, in exactly the conditions that had supposedly occasioned their older sibling's removal. Although the SCRD preferred boarding out, Aboriginal children were, almost universally, institutionalised in Cootamundra Training School for a brief period then sent out to service in wealthy homes ${ }^{63}$. By this time fewer than $20 \%$ of state children in NSW were apprenticed, because children themselves chose other forms of employment and the welfare agencies thought domestic apprenticeship limited children's opportunities to become skilled workers. $70 \%$ of the children it removed were girls. ${ }^{64}$ The Board justified this by arguing girls needed to be protected from moral degradation by being removed from reserves before puberty, but this rings hollow when it is considered that $11 \%$ of wards became pregnant whilst in care. Fewer than $4 \%$ of the Tasmanian wards I studied and just $1 \%$ of those considered by Barbalet became pregnant. ${ }^{65}$ Although, in the longer run, as many as $65 \%$ of wards returned to Aboriginal communities, their time away had a destructive effect, haunting Aboriginal family life. Ironically, it also inspired a protest movement that began in the 1920s, and only concluded in 2008, with Kevin Rudd's apology.

\section{The reality of life for boarded out children}

The racism and gender bias of the Aborigines Protection Board is stark, but there is no basis for assuming that non-Aboriginal children had any better care under the SCRD. In 1916 and 1917, two government inquiries considered whether state children really were improved by boarding out, and removal from the city environment to rural districts. The first inquiry, a Select Committee in 1916, arose from disputes within the public service 
about whether the correct function of the SCRD was education or charity. The second, in 1917, was a Public Service Board inquiry into allegations made by an organizer for the Political Labour League, J.F. Hackett, who claimed children fostered out in the Hawkesbury River area were living in slavery. ${ }^{66}$ Ultimately, these inquiries endorsed the status quo, but they offer compelling insights into contemporary thinking about child welfare, children's work and the standards of living state children were expected to accept. They show just how a system intended to be protective and helpful, could end up harming children.

33 Mackellar, still active in welfare circles and agitating in favour of the SCRD taking an educative role, told the first enquiry that the SCRD existed for pre-emptive social intervention, to curb criminality:

"In my opinion, neglected children are ipso facto delinquent children. They are children who have had drunken, worthless, or criminal parents, or they are children of prostitutes, or of people who have been in gaol. Such children readily become delinquents." ${ }^{67}$

Mackellar was speaking to the fear of government and bureaucrats about the social cost of failing to curb children, who, unfettered, would surely contribute to the criminal classes. While Hackett sought to develop boarding schools for state children, Mackellar invoked the old fear of institutions, saying:

"You do not alter the character of an institution by changing its name. You may call

it a State Boarding School, an Orphan School, an Industrial School, or a

Reformatory. Practically they are all the same."68

Mackellar's words proved effective at reminding the government that state children were a threat to society. While the government decided the SCRD's role was charitable, it refused to countenance any extension of educational programmes within the Department. The boarding out system remained intact. ${ }^{69}$

However, the Public Service Board inquiry into conditions in the Hawkesbury showed just how children were being let down - and abused - within state care. It was triggered by the agitations of Hackett, who said he was driven to make his complaints by his own observation of the state of boarded out children through his work as a travelling salesman. He presented 40 complaints of overwork and abuse from Hawkesbury River towns to the inquiries, and the Public Service Board and police made surprise visits to investigate. ${ }^{70}$ There were 139 children in 73 homes in the area, about 60 kilometres from Sydney. ${ }^{71}$ The police told the inquiry they thought children should work, and that they thought a healthy 14-year-old could milk 6 cows and attend to stock and poultry without affecting his or her schoolwork. However they said most children in the area were overworked, providing some brutal examples. One Chinese 'half-caste' foster child made the fire, milked a cow, fed 5 pigs and chopped the day's wood before breakfast, then walked 5 kilometers to school, in winter, wearing only a thin cotton jacket..$^{72}$ The police said 1 boy of 9 had lost his fingers in a chaff cutter and that many of the boys they interviewed were 'low-spirited' because of the amount of work they had to do. ${ }^{73}$ The police also reported that the majority of guardians were so poor they struggled to clothe children properly, and few state children wore boots, even in winter. One foster boy slept with an apprentice in a room with broken windows, on a dirty stretcher filled with chaff. Police stated that the children were wanted by locals because the foster allowances provided a source of income - one foster mother had up to 13 children at once, and another very poor woman survived solely on the foster allowance for her 6 wards. A 
number of foster carers said they took children so the government would continue to provide a school for the area. ${ }^{74}$

The President of the SCRD, A.W. Green, argued state children, which, he carefully pointed out were 'incorrigible' and 'truants and court boys' and, therefore delinquents in the making, could expect no better than this. He dismissed the problems highlighted by police reports into the poverty of carers, saying the 'motherly care' of foster mothers compensated for 'any deficiency in the way of fine furniture and polish' and that 'a broken window is better than a closed window', because it admitted healthful fresh air. Bare feet were also preferable to wet boots. As well, he argued:

"These people have brought up their families in these places. If they can deal with their own families they can deal with our children. We deal with it in this way that the children must be treated as their own children." 75

If not boarded out, Green said, these children would be institutionalised. Green thought the unhappiness of the children was not due to abuse, but simply because they longed for home and wanted to get back to their mothers. ${ }^{76}$

Hackett's perspective on that was the boarding-out system was child slavery, for children were not fostered for love, but for what foster parents 'can get out of them'. ${ }^{77}$ His first witness was a woman who had sent her son to a state institution in the hope he would be sent home 'a manly and good boy'. However, he was apprenticed, without her knowledge or consent, to a dairy farmer at Kempsey, where he was, she alleged, overworked until he sickened and died of typhoid. ${ }^{78}$ She said:

"I think [the farmer] was kind enough to wrap up the whip he had flogged him with

... some other little trinkets my boy had, and he gave them to me to bring home. I

have the whip at home." 79

Green discredited her, and diminished her as a mother, by presenting reports that her family was 'improper'. The mother sobbed 'I have had a hard life, I defy anyone to say I am not a good woman and a good mother', but the Public Service Board agreed she should be "taken no more notice of. ${ }^{80}$ Allegations made by a local farmer that his neighbours lived off the sweated labour of children and punished them by tying them to orange trees with trace chains were similarly dismissed, as hearsay, although no attempt had been made to investigate them. ${ }^{81}$

The Government pre-empted the findings of the inquiries, boasting in Parliament they would find against Hackett and show 'the children were in every case happy and bright, and quite satisfied with their surroundings' ${ }^{82}$ As the Select Committee concluded, Green was given the last word, and told Hackett 'the boarding-out system is the best in the world. You cannot suggest any better'. He bluntly stated 'it is the policy of every decent person for a child to do work'. ${ }^{83}$

The inquiries duly found that SCRD foster homes were 'a credit to the State'. They also said it was clear that state children required strict discipline, and that the boarding of children in private homes and at Mittagong was done 'with care, foresight and humanity'. ${ }^{84}$ Boarding-out, and child labour, had received a ringing endorsement and would not face serious scrutiny again. 


\section{Conclusion}

43 improvement and the betterment of society, was pervasive. Boarding out, or fostering, remained unquestioned, although numbers declined as a better system of welfare payments improved living conditions for families. Apprenticeship remained a feature of Aboriginal wardship until World War II when the Board, reconstituted as the Aborigines Welfare Board, decided assimilation was best affected by placing younger children in white homes.

These ideas, of the redemptive power of children's labour, were also held by the religious and charitable organisations who arranged 'care' for the child migrants sent out from Britain after World War II. They used institutionalisation and labour, to offset the cost of running the institutions and to make the children 'useful'. As had been the case with state wards and Aboriginal children, these schemes were positioned as 'rescue', from the poverty and social dislocation of Britain, and many were presented as orphans. ${ }^{85}$ This familiar trope helped raise funds and appease those who might oppose the importation of cheap labour, such as the labour movement. ${ }^{86}$ The image presented to the outside world at the time was of 'orphaned and abandoned' British children being made rosy-cheeked by physical work and opportunity in the great Australian outdoors.

But, as David Hill has argued, child migration schemes proved to be a lie and the Australian Senate's inquiries have certainly shown this to be the case. ${ }^{87} \mathrm{Few}$ questions were asked. The New South Wales Government, having endorsed its own schemes of child labour, was hardly going to question religious and charitable organisations for putting children to work. The Australian public had long been told the ills of urban slums or Aboriginal reserves could be corrected by the placing children in a new setting, and inculcating 'habits of industry', and that such programmes benefited the child and society. Child migration schemes, like the Aborigines Protection Board and the SCRD before them, took social problems out of plain sight. The tragedy was they also made the children in those schemes, and their suffering, invisible.

I am grateful to the unnamed readers of this article, and to Shurlee Swain and Caroline Evans for their comments on drafts of this paper.

\section{NOTES}

1. Swain Shurlee, SheEdy Leonie, MusGrove Nell, "Responding to 'Forgotten Australians': historians and the legacy of out-of-home 'care"', Journal of Australian Studies, 36:1, p. 17-28.

2. PARRY Naomi, “'Such a Longing': Black and White Children in Welfare in NSW and Tasmania, 1880-1940" (UNSW, PhD, 2007), [

http://trove.nla.gov.au/work/4033481

], accessed 1.12. 2011. 
3. SWAIN Shurlee, SHEEDY Leonie, MUSGRove Nell, "Responding to 'Forgotten Australians”, p. 21.

4. BRISKMAN Linda, The Black Grapevine: Aboriginal Activism and the Stolen Generations (Sydney: 2003), p. 101-107.

5. READ Peter, The Stolen Generations: The Removal of Aboriginal Children in NSW 1883-1969 (Sydney: Ministry of Aboriginal Affairs Occasional Paper 1 and Aboriginal Children's Research Project (Family and Children's Services Agency), 1981; “The Return of the Stolen Generation," Journal of Australian Studies, December 1998.

6. Human Rights and Equal Opportunities Commission, Bringing Them Home. National Inquiry into the Separation of Aboriginal and Torres Strait Islander Children from Their Families (Canberra, 1997).

7. Federal Government Submission, Senate Legal and Constitutional Committee, "Inquiry into the Stolen Generation" (Commonwealth: Senate, 2000), Executive Summary, p. ii.

8. MANNE Robert, "In Denial: The Stolen Generations and the Right," The Australian Quarterly Essay 1, 2001.

9. GILL Alan, Orphans of the Empire: The Shocking Story of Child Migration to Australia (Sydney: Vintage, 1998), p. 85-86; In the 1920s drought and recession in Canada reduced the demand for child migrants, while a British delegation led by Margaret Bondfield MP raised concerns about aftercare. LANGFIELD Michele, "Voluntarism, Salvation, and Rescue: British Juvenile Migration to Australia and Canada, 1890-1939", Journal of Imperial \& Commonwealth History, 32, 2, 2004, p. 86-114.

10. Studies of the transportation of juvenile criminals provide valuable information about attitudes to children that are outside the scope of this study. For instance SHORE Heather, "Transportation, Penal Ideology and the Experience of Juvenile Offenders in England and Australia in the Early Nineteenth Century," Crime, Histoire \& Sociétés / Crime, History \& Societies, 6, 2, 2002, p. 81-102.

11. GILL Alan, Orphans of the Empire; BEAN Phillip, MELVILE Joy, Lost Children of the Empire (London: Unwin Hyman, 1989); M. Humphreys, Empty Cradles (London: Corgi, 1994); SHERINGTON Geoffrey and JEFFERY Chris, Fairbridge: Empire and Child Migration (Perth: University of Western Australia Press, 1998).

12. Senate Community Affairs References Committee, Lost Innocents: Righting the Record (Canberra: Parliament House, 2001).

13. Ibid., Submission 57, cited p. 104-105.

14. PENGLASE Joanna, Orphans of the Living: Growing up in "care" in twentieth-century Australia, (Fremantle: Fremantle Arts Centre Press, 2005).

15. Senate Community Affairs References Committee, Forgotten Australians: A report on Australians who experienced institutional or out-of-home care as children, (Canberra: Parliament House, 2004).

16. Senate Community Affairs Reference Committee, Forgotten Australians, p. Xv-Xvi.

17. READ Peter, "Clio or Janus? Historians and the Stolen Generations," Australian Historical Studies 118, 2002, p. 54-60.

18. WIMSHURST Kerry, "Control and Resistance: Reformatory School Girls in Late Nineteenth Century South Australia”, Journal of Social History, 18:2, 1984, p. 273-287; DICKEY Brian, “The Establishment of Industrial Schools and Reformatories in New South Wales, 
1850-1875," Journal of the Royal Australian Historical Society [JRAHS] 54: 2 (1968); QUINN Peter, “"We Ask for Bread and Are Given Stone': The Girls Industrial School, Parramatta, 1941-1961," JRAHS 75, n 2 (1989); WILLIAMSON Noeline, “'Hymns, Songs and Blackguard Verses': Life in the Industrial and Reformatory School for Girls in New South Wales, Part I, 1867 to 1887," JRAHS 67, $\mathrm{n}^{\circ}$ March, Pt. 4 (1982); "Laundry Maids or Ladies? Life in the Industrial and Reformatory School for Girls in New South Wales, Part II, 1887 to 1901," JRAHS 68, n 4, March (1983); wILlis Sabine, "Purified at Parramatta: The Industrial School for Girls," In Pursuit of Justice: Australian Women and the Law 1788-1979, ed. Mackinolty J., Radi H. (Sydney: Hale \& Iremonger, 1979).

19. DICKEY Brian, No Charity There: A Short History of Social Welfare in Australia, 1st ed., (Sydney: Allen \& Unwin, 1980), p. 80.

20. DICKEY Brian, No Charity There: A Short History of Social Welfare in Australia, $2^{\text {nd }}$ ed., (Melbourne: Thomas Nelson Australia, 1987); HORSBURGH Michael, “The Randwick Asylum: Organizational Resistance to Social Change," Australian Social Work 30, 1, March 1976, p. 15-24.

21. State Children's Relief Department [SCRD] Annual Report, (Sydney: NSW Parliamentary Papers), 1882, p. 3; RATHBONE R. W., A Very Present Help: the history of the Benevolent Society of NSW, (Sydney: Benevolent Society/State Library of NSW Press, 1994), p. 81.

22. PARRY, "Such a longing", p. 26-29.

23. DICKEY Brian, No Charity There, $1^{\text {st }}$ ed., p. 63; HORSBURGH Michael, "Child Care in New South Wales in 1870," Australian Social Work 29, 1, March 1976, p. 3-24; "Child Care in New South Wales in 1890," Australian Social Work 30, 3, September 1977, p. 21-30; "The Randwick Asylum"; "Government Policy and the Benevolent Society," JRAHS 63, September 1977, p. 77-91.

24. HORSBURGH Michael, "Child Care in New South Wales in 1890," p. 21.

25. SCRD Annual Report, 1915, p. 60.

26. SCRD Annual Report, 1899, p. 2.

27. SCRD Annual Report, 1899, p. 2.

28. TIFFIN Susan, In Whose Best Interest? Child Welfare Reform in the Progressive Era (Connecticut: Greenwood Press, 1982), p. 61-101; SwIFT K. J., “An outrage to common decency: historical perspectives on child neglect," Child Welfare, 74, 1, 1995, p. 71-91.

29. SWAIN Shurlee, "Child Rescue: The Emigration of an Idea," in Child Welfare and Social Action in the Nineteenth and Twentieth Centuries, ed. J. Lawrence, P. Starkey (Liverpool: Liverpool University Press, 2001), p. 103-104; ScoTT D. \& SWAIN Shurlee, Confronting Cruelty: Historical Perspectives on Child Protection in Australia (Melbourne: Melbourne University Press, 2002), p. 15.

30. PARRY, "Such a Longing", p. 22-33; EVANS Caroline, "Protecting the Innocent: Tasmania's Neglected Children, Their Parents and State Care, 1890-1918" (University of Tasmania, Department of History, PhD Thesis 1999).

31. PARRY, "Such a longing”, p. 32.

32. Ibid., p. 125.

33. Ibid., p. 141-142. 
34. SCRD Annual Report, 1882, p. 6-7, RITTER Leonie, "Boarding-Out in New South Wales and South Australia: Adoption, adaptation or innovation?," JRAHS, 64, September, 1978, p. 120-126.

35. PARRY, "Such a longing", p. 31-32.

36. PARRY, "Such a longing", p. 154-183.

37. Aborigines Protection Association, Annual Report, 1881, p. 1.

38. Aborigines Protection Board [APB] Annual Report (Sydney: NSW Parliamentary Papers), 1883, p. 4.

39. TIFFIN Susan, In Whose Best Interest?, p. 61-101; sWIFT Karen J., "An outrage to common decency: historical perspectives on child neglect," Child Welfare, 74, 1, 1995; PASCOE Peggy, Relations of Rescue: The Search for Female Moral Authority in the American West, 1874-1939 (New York: Oxford University Press, 1990); GISH Clay, "Rescuing the 'Waifs and Strays' of the City: The Western Emigration Program of the Children's Aid Society, Journal of Social History, 33, 1, 1999, p. 121-141.

40. PISciotTA Adrian W., "Treatment on Trial: The Rhetoric and Reality of the New York House of Refuge, 1857-1935," American Journal of Legal History 29, 1985, p. 151-181; KUNZEL Regina G., Fallen Women, Problem Girls: Unmarried mothers and the professionalization of social work 1890-1945, (New Haven: Yale University Press, 1993); ALEXANDER Ruth M., The "Girl Problem": Female Sexual Delinquency in New York, 1900-1930 (Ithaca: Cornell University Press, 1995); oDEM Mary, "Single Mothers, Delinquent Daughters, and the Juvenile Court in Early 20th Century Los Angeles," p. 27-43; Delinquent Daughters (Chapel Hill: University of North Carolina Press, 1995); GORDON Linda, "Black and White Visions of Welfare: Women's Welfare Activism, 1890-1945", The Journal of American History, 78, 2, 1991, p. 559-590; PEEBLES-WILKINS Wilma, "Janie Porter Barrett and the Virginia Industrial School for Colored Girls: Community response to the needs of African American Children", Child Welfare, 74, 1, 1995, p. 143 ; HORNSBY Angela M., “'The Boy Problem': North Carolina Race Men Groom the Next Generation, 1900-1930," The Journal of Negro History, 86, 3, 2001, p. 276-304; COLLMEYER Patricia, "From 'operation brown baby' to 'opportunity': The placement of children of color at the Boys and Girls Aid Society of Oregon", Child Welfare, 74, 1, 1995, p. 242-263.

41. KATZ Michael B, In the Shadow of the Poorhouse: A Social History of Welfare in America (New York: Basic Books Inc., 1986); TIFFIN, In Whose Best Interest?, p. 6-10.

42. GARTON Stephen, "Sir Charles Mackellar: Psychiatry, Eugenics and Child Welfare in NSW, 1900-1914," Australian Historical Studies 22, 86, 1986; MITCHELl A. M., "Sir Charles Kinnaird Mackellar (1844-1926)," Australian Dictionary of Biography 1891-1939, [

http://adb.anu.edu.au/biography/mackellar-sir-charles-kinnaird-7382

], accessed 2011/12/01.

43. VAN KRIEKEN Robert, Children and the State: Social Control and the Formation of Australian Child Welfare, (Sydney: Allen \& Unwin, 1991); Ludlow Christa, "For Their Own Good": A History of Albion Street Children's Court and Boys' Shelter (Sydney: Network of Community Activities, 1994); PLATT Anthony M., The Child Savers: The Invention of Delinquency, 40th Anniversary edition, Rutgers University Press, 2009.

44. KUNZEL, Fallen Women, Problem Girls, p. 53. 
45. GARTON, "Sir Charles Mackellar", p. 23, p. 31; wATts Richard, "Beyond Nature and Nurture: Eugenics in Twentieth Century Australian History," Australian Journal of Politics and History 40, 3, 1994; ROE Michael, Nine Australian Progressives, Vitalism and Bourgeois Social Thought 1890-1960 (St Lucia: University of Queensland Press, 1984); EVANS Caroline, PARRY Naomi, "Vessels of Progressivism? Tasmanian State Girls and Eugenics, 1900-1940," Australian Historical Studies 117, 2, 2001.

46. SCRD Annual Report, 1907, p. 24-25.

47. SCRD Annual Report, 1907, p. 24-25; SANGSTER J., "Masking and Unmasking the Sexual Abuse of Children: perceptions of violence against children in 'the badlands' of Ontario, 1916-1930," Journal of Family History, 24:4, 2000.

48. MACKelLar Charles, The Treatment of Neglected and Delinquent Children in Great Britain, Europe, and America: With Recommendations as to Amendment of Administration and Law in New South Wales (Sydney: Government Printer, 1913).

49. Ibid., p. 90-91.

50. GOODALL, Heather, “'Assimilation Begins in the Home': The State and Aboriginal Women's Work as Mothers in New South Wales, 1900s to 1960s," Labour History 69, 1995; Invasion to Embassy, Land in Aboriginal Politics in NSW, 1770-1972 (Sydney: Allen \& Unwin, 1996).

51. GAPPS Stephen, "Mr Ardill's Scrapbook: Alternative Sources for Biography," Public History Review 2, 1993; RADI Heather, "George Edward Ardill 1857-1945," Australian Dictionary of Biography 1891-1939; The Rescue VII-XIV, 1900-1910; PARRY, "Such a Longing", p. 169-183; "George E. Ardill," The Australian Workman, 7 March 1891.

52. APB Annual Report 1907, p. 4.

53. NSW Aborigines Protection Act 1909, No 25.

54. APB Annual Report 1909, p. 2.

55. APB Annual Report, 1910, p. 4.

56. APB Annual Report, 1911, 'Act and Regulations', p 2.

57. GISH, "Rescuing the 'Waifs and Strays' of the City".

58. PARRY, "Such a longing", p. 176-179.

59. NSW State Records Authority, Aborigines Welfare Board, Ward Registers 1916-1928, 4/8553-8554; NSW State Records Authority, Minutes, Aborigines Welfare Board, 4/7121, 1912/08/01; 1912/02/05; 4/7122, 1912/08/22, 1912/09/12, 192/11/21, 1912/11/28.

60. SCRD Annual Report, 1915, p. 28,

61. PARRY, "Such a longing", p. 279-283.

62. PARRY, Ibid., p. 289.

63. PARRY, Ibid., p. 285-287; CHISHOLm Richard, Black Children, White Welfare? Aboriginal Child Welfare Law and Policy in New South Wales, University of New South Wales Social Welfare Research Centre Monograph, vol. 52 (Sydney: UNSW Social Welfare Research Centre, 1985); COLE Anna, "Would Have Known It by the Smell of It': Ella Hiscocks" and HASKINS Victoria, “'A Devotion I Hope I May Fully Repay': Joan Kingsley-Strack,” in Uncommon Ground: White Women in Aboriginal History, ed. Cole Anna, Haskins Victoria, Paisley Fiona, (Canberra: Aboriginal Studies Press, 2005), p. 153-172; Goodall, "Saving the Children"; "Assimilation Begins in the Home"; HASKINS Victoria, "Could You See to the Return of My 
Daughter?": Fathers and Daughters under the New South Wales Aborigines Protection Board Child Removal Policy," Australian Historical Studies 34, 121, 2003, p. 106-121; “"A Better Chance'? Sexual Abuse and the Apprenticeship of Aboriginal Girls under the NSW Aborigines Protection Board," Aboriginal History 28, 2004, p. 33-58; "\& So We Are "Slave Owners'!": Employers and the NSW Aborigines Protection Board Trust Funds," Labour History 88, May 2005; One Bright Spot (Houndmills: Palgrave Macmillan, 2005); WALDEN Inara, “'That Was Slavery Days': Aboriginal Domestic Servants in New South Wales in the Twentieth Century," Labour History 69, 1995, p. 196-209; “"To Send Her to Service': Aboriginal Domestic Servants," Aboriginal Law Bulletin 3, 76, 1995, p. 12-14.

64. PARRY, "Such a longing", p. 285-289, p. 328.

65. BARBALET, Far From a Low Gutter Girl, p. 92-94, p. 239, Cited PARRY, “Such a longing”, p. 293.See p. 292-297 for full discussion of pregnancy rates.

66. NSW Public Service Board, Public Service Board Report in regard to the conduct of the State Children's Relief Department, particularly in regard to the boarding-out of children under alleged undesirable conditions (Sydney: NSW Parliamentary Papers, 1917), p. v; Select Committee, State Children Relief Act, 1901 - Select Committee into the Whole Administration of, (Sydney: NSW Parliamentary Papers, 1916), p. 3-6, p. 22.

67. Ibid., p. 41-44; MITCHELL, "Mackellar, Sir Charles Kinnaird (1844-1926)".

68. Select Committee into State Children Relief Act, 1916, p. 41.

69. PARRY, "Such a longing", p. 240-244.

70. Public Service Board Inquiry into SCRD, p. v. Select Committee, State Children Relief Act, p. 9.

71. SCRD Annual Report 1915, p. 11.

72. Select Committee, State Children Relief Act, p. 9.

73. Daily Telegraph, 18 June 1916; Public Service Board inquiry into SCRD, p. 3.

74. Public Service Board, Inquiry into SCRD, p. 2-4.

75. Ibid., p. 5.

76. Public Service Board, Inquiry into SCRD, p. 18; Select Committee, State Children Relief Act, p. 17-19.

77. Select Committee, State Children Relief Act, p. 23-24.

78. Ibid., p. 24-25; p. 38-39.

79. Ibid., p. 36-37.

80. Ibid., p. 39.

81. Ibid., p. 10-15.

82. Arthur Griffith, 1916/05/09, Parliamentary Debates No. 27, page 1398, cited Ibid., p. 63.

83. Ibid., p. 62.

84. Ibid., p. vii-viii.

85. GILL, Orphans of the Empire, p. 40.

86. GILL, Orphans of the Empire, p. 102, 142.

87. HILL David, The Forgotten Children: Fairbridge Farm School and Its Betrayal of Australia's Child Migrants (North Sydney: Random House, 2007). 


\section{ABSTRACTS}

Three Australian Government inquiries have changed the way child welfare history is perceived in Australia over the last 15 years by bringing to light the stories of children displaced from their birth family and communities of origin; the stolen generations of Indigenous children, British child migrants and those who grew up in out-of-home care. Each inquiry found evidence of physical, emotional and sexual abuse of children and failures of a duty of care by welfare agencies, religious organisations and governments. The Australian Government has apologized to affected children but historians have only just begun the work of understanding what drove these policies. This paper examines the years 1909-1917, in which the Aborigines Protection Board established its policies towards children and the NSW Government investigated the State Children's Relief Department's system of boarding out children. The common belief between the two systems was that removal of children protected society, from delinquency and immorality, and their labour was redemptive. These beliefs established a low threshold for the care of these children, and affected the reception and care of later child migrants.

En Australie, depuis une quinzaine d'années, trois enquêtes gouvernementales ont changé la perception de l'histoire des politiques de protection de la jeunesse. La question des enfants déplacés hors de leur famille ou de leur communauté, celui des "générations volées" autochtones, des jeunes orphelins britanniques et de tous les enfants ayant grandi en dehors d'un foyer familial fait désormais partie du débat public. Chaque enquête a fait la preuve des violences physiques, psychiques et des abus sexuels dont les enfants ont été victimes, révélant les manquements dont se sont rendus responsables les organisations de bienfaisance, les communautés religieuses et l'État. Le gouvernement australien a présenté ses excuses aux victimes, mais les historiens doivent encore mettre au jour les fondements de ces pratiques. Cet article examine les années 1900-1917, lors desquelles la Commission de protection des Aborigènes (Aborigines Protection Board) a mis en place ses politiques, alors que le Gouvernement de Nouvelle Galles du Sud enquêtait sur le réseau des internats de placement d'enfants du Département pour la protection des enfants sous tutelle de l'État (State Children's Relief Department). Les deux instances partageaient cette conviction selon laquelle le retrait des enfants de leur milieu garantissait à la fois la protection de la société et la protection des enfants de la délinquance et de l'immoralité, discipline fondée sur une mise au travail rédemptrice. Cette doctrine n'a laissé que peu de place au soin et à l'éducation, affectant la vie de nombreux enfants au long du xxe siècle.

\section{INDEX}

Mots-clés: histoire, enfance, Australie, générations volées, Aborigènes, politiques raciales, colonisation

Keywords: History, stolen children, Australia, removal, Aborigines, Protection Board, colonisation 


\section{AUTHOR}

\section{NAOMI PARRY}

Research fellow, Australian Catholic University, Faculty of Arts and Sciences 